
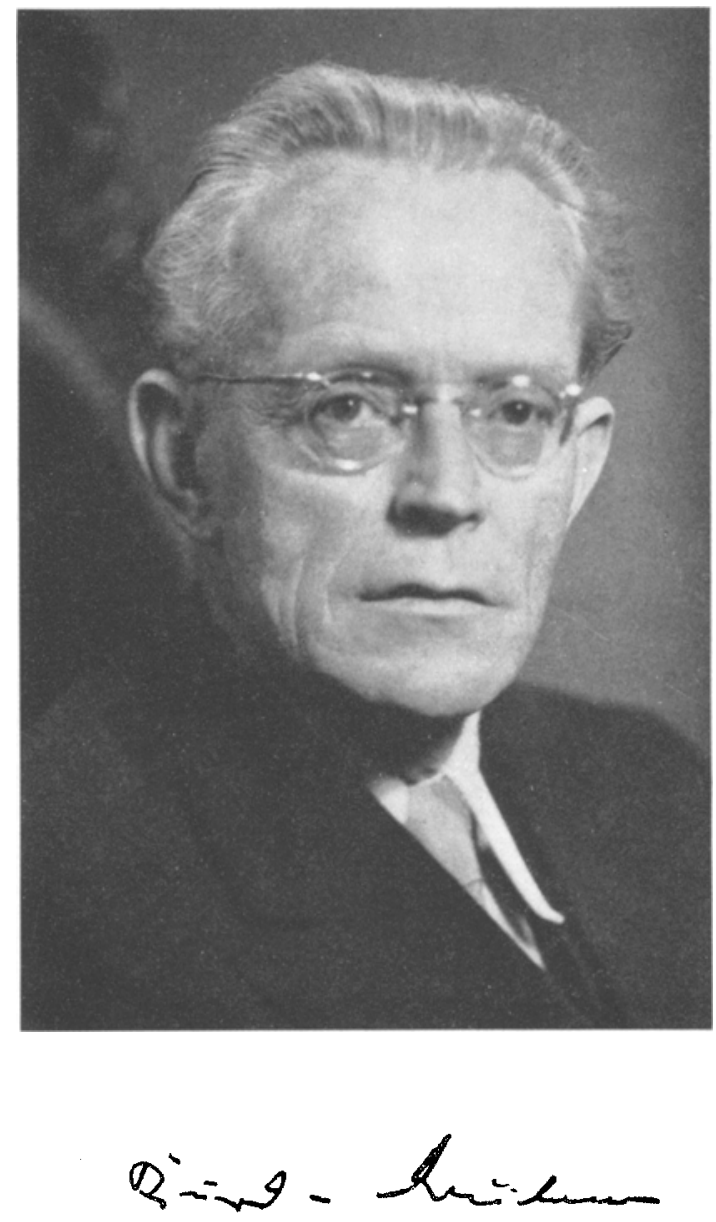

Die Geologische Vereinigung verlieh im Jahre 1971 die Gustav-Steinmann-Medaille

an

\title{
Professor Dr. Kurd von Bülow
}

der neben grundlegenden eigenen Forschungen

zwischen Moor und Mond

unsere Geologie breiten Kreisen zugänglich machte 